system and general muddle-headedness in business matters for which doctors, as a class, are almost a by-word.

I feel that I must offer some apology for these disconnected musings which have been rather hurriedly put on paper in response to an appeal at short notice for a contribution. They are but a poor substitute for the finished dissertation which the title demands, nor can they pretend to give more than the faintest impression of the many dreams and aspirations, in which, in common with others who cherish the honour of our profession, I have ventured in moments of speculation to indulge. Medicine, in whatsoever aspect it is approached, is indeed a vocation, and those who seek through its profession to discover the philosopher's goal are apt to find it a pathway in which, if I may be permitted a paradox, "many are chosen but few are called." It is, perhaps, impossible to analyse the various motives, worthy or unworthy, which induce men to join the ranks. Here it can only be said that they are numerous, and that of all who enter the medical schools year by year the number of those who are truly inspired by the love of the Art for its own sake is probably small. It is to such as these that the vision of ideals will appear with the most alluring light. To them will the counter-calls of Science and Philosophy make their strongest appeal. It is they who, in the unharmonious search for that synthesis of knowledge which is the dream of their lives, will suffer, like poor Tyrrell, that pain of disappointment which is reserved only for those strong yet gentle spirits who are the very salt of the earth, and who, after the manner of all their kind, remain faithful unto death. The ideals of Medicine are like that true romance which is indeed the veil between the law of the universe and man's infirmity.

"Thy face is far from this our war,

Our call and counter-cry,

I shall not find Thee quick and kind, Nor know Thee till I die.
Enough for me in dreams to see And touch Thy garment's hem ;

Thy feet have trod so near to God, I may not follow them."

Nevertheless the attempt should be made, and those who have philosophy enough to begin and to continue their medical career in this spirit will not only contribute all the more to the treasures of human thought, but will find in their profession the greatest romance that this life can offer them.

\section{CALCIUM METABOLISM AND TREATMENT.}

a Clinical, post-gradeate lecture at THE RUYal. WATERLOO HOSPITAL.

\section{By GERALD M. SLOT,} M.D., M.R.C.P., D.P.H.,

Physician to the Royal Waterloo Hospital and Royal Hospital, Richmond; Consulting Physician, Hammersmith Hospital; Harmsworth Memorial Fellow; Physician-in-Charge, L.C.C. Rheumatism Centre, \&c.

DURING the past ten years, an enormous amount of work has been done on the subject of calcium metabolism ; it will, however, be the object of this lecture not to dwell on the physiological aspect so much as on the therapeutic aspect of calcium.

Calcium is a normal constituent of all the tissues of the body and of course forms the basis of the skeleton.

If patients are fed on calcium deficient diets-the calcium content of the bones is lowered (Vines), while, as Rost has pointed out, very prolonged administration of calcium by mouth may increase the calcium content of the bones; this fact has not, however, been confirmed by other workers such as Korenchevsky, and in the light of clinical experience I think must remain open to doubt.

I have never succeeded in raising the blood calcium of any patient by the oral administration of calcium, and the experi- 
mental work of Mason, Dennis and Minot especially would indicate that calcium is unabsorbed from the intestinal tract.

Calcium normally exists in the blood serum in two forms-a diffusible form and a non-diffusible form.

When serum is passed through collodion, it is found that $6 \mathrm{mg}$. pass through the collodion filter while $4 \mathrm{mg}$. are in some diffusible compound with the protein.

This figure remains very constant and there must be probably some mechanism to balance the excretion and absorption of calcium.

One of the most important facts in calcium metabolism is its relation to phosphates in the calcification of cartilage.

Harden and Robison have isolated from fermentation mixtures a hexose monophosphate which was found to yield soluble barium and calcium salts. Robison discovered that certain enzymes caused hydrolysis with the deposition of calcium and barium phosphate-and he further showed that cartilage has the power to hydrolyse these esters.

If, as Drummond points out, we regard the serum and body fluids as saturated solutions, there are certain conditions which must lead to the deposition of calcium phosphate or carbonate. A rise in the concentration of phosphate and carbonate ions occurs either when there is an increase in the concentration of inorganic phosphates, or when there is a reaction to the alkaline side. Extra force is added to this alkalinity factor in the light of Robison's work, showing that the optimum activity at a centre of ossification is $\mathrm{pH}^{\circ} \cdot 4$ to 9.4 -a very much higher figure than that found in ordinary tissues.

Time will not allow a further discussion of the interesting speculations which follow, but in view of the association between this by-product of sugar fermentation and calcium metabolism, I agree entirely with Drummond in the view that there is a very probable correlation between calcium, phos- phate and carbohydrate metabolism and the diseases such as rickets and tetany.

In therapeutics, calcium is often given by the mouth.

As Stewart and Percival have shown, the main excretory route for calcium is via the large intestine.

The only drug which is known to have certain pharmacological action on calcium metabolism is the parathyroid.

Stewart and Percival have demonstrated that by the use of an active parathyroid extract the serum calcium of cats is raised when calcium is injected subcutaneously and even more when injected intravenously. The parathyroids, however, do not act by controlling excretion, because following the administration of parathyroid and during the high phase of serum calcium, there is no diminution in the rate of calcium excretion and it is probable that the parathyroid hormone may control the distribution of calcium between the blood and tissues. The investigations of Hunter and Aub using Collip's active extract (parathormone) seems to show that parathormone caused considerable excretion of calcium from the bones.

The method of estimating blood-calcium is simple and accurate and has been fully described by Kramer and Tisdall.

The part played by calcium in the living body is not as yet accurately known. Certain definite facts are recognized.

In isolated heart muscle an increase of calcium in the perfusion fluid causes a contraction and without calcium the heart-beats will cease ; in the presence of an excess of calcium contractions continue, until a state of rigor known as calcium rigor is reached.

In ordinary muscle a decrease of calcium content causes an increase in irritability.

Matz and Cantorow have shown that the serum calcium in hamophilia is associated with a reduction in coagulation time.

\section{INDICATIONS FOR CALCIUM THERAPY.}

The indications for calcium therapy were fully discussed by Fraser and others at the 
British Medical Association in 1927. A good deal of variance of opinion was expressed-from assertions that its use is merely palliative to statements that it effected an absolute cure. In nephritis Blum has shown that in cases where salt-free diet or the ordinary diuretics had failed to cause a reduction of the ascites or œdema, massive dosage of calcium chloride, especially when associated with a salt-free diet, had caused a rapid diminution of the œdema. This action is based on Blum's assumption that by increasing the ionic calcium, the ionic sodium is diminished-and it is a sodium retention which is largely associated with the presence of œdema.

In severe nephritis, as Marriott and Howland, Linder and Salvesen have shown, the total serum calcium is reduced, and in the azotæmic type this is associated with a rise in the serum phosphate. De Wesselow has suggested that this may be due to a phosphate retention and consequent disturbance of $\mathrm{Ca}\left(\mathrm{PO}_{4}\right)$ balance. Fraser states that he knows of no beneficial result in any case of this type which has occurred either by raising the blood-calcium by parathormone or by the actual administration of calcium.

In treating his cases, Blum uses 300 to $600 \mathrm{gr}$. of calcium chloride by mouth a day. I have found benefit in some cases by this method of treatment but it has certain disadvantages. In some cases this intensive dosage causes nausea and in one case the vomiting was very persistent. It may be that in these cases it is not entirely a calcium effect that causes improvement. It may be, as Fraser has suggested and Blum admits, that the increased acidity caused by the chloride ions causes an increase in the amount of sodium which is excreted-in the form of sodium chloride and water.

In tetany there are two main groups. In the first there is a normal serum calciumthis type occurs in acute gastric dilatation (post-operative tetany), over-breathing or taking of large doses of ammonium chloride (Huxley)-and as Linder has pointed out in this type the effectiveness of the calcium $\stackrel{c}{\Rightarrow}$ is greatly diminished by an abnormal in- $\stackrel{5}{+}$ crease in the $\mathrm{pH}$ or a rise in the bicarbonate or phosphate.

In the second group the serum calcium is definitely decreased. This includes infantile, parathyroid and intestinal tetany. The application of Collip's work here assumes? a great importance, because in these cases $\vec{\omega}$ the intravenous administration of calcium together with parathormone produces dramatic results. In the presence of rickets, it is wise to omit the parathormone because, $\vec{\oplus}$ as has been mentioned above, this substance drains the calcium from the bones-and there is already a dearth in this condition.

Many interesting points have been $\subseteq$ observed in this condition. It has been found that in intestinal tetany large doses of $\overrightarrow{0}$ calcium chloride (Io grm. a day) gave relief but $20 \mathrm{grm}$. of calcium lactate were of little immediate use. Here again it is probable that it is, the acid-base factor that is of importance. Linder mentions a case of parathyroid tetany in which no improvement $\overrightarrow{\overrightarrow{0}}$ was observed until foci of sepsis were re- 3 removed, and makes the interesting suggestion that sepsis may vitiate the action of parathormone in the same manner as it 3 does that of insulin.

\section{Calcium Therapy.}

I have had very disappointing results, as I have stated above, in calcium administration by the mouth. Some workers deny that any serum calcium rise is obtained at all when it is exhibited by this method, and 0 that according to Fraser a very large dose $\underset{\sigma}{\sigma}$ (5-10 grm. by the mouth) may cause a rise of not more than $2 \mathrm{mg}$. per Ioo c.c.

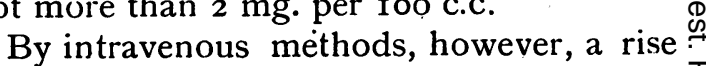
can be secured immediately - a rise of over roo per cent. being obtained in some cases. Sloughing has been recorded following the intravenous use of calcium chloride, but $\mathrm{I}$ 울 have now used calcium gluconate made by 8 the Sandor Company both intravenously 
and intramuscularly in a very large number of cases and have never had any bad results either general or local.

There is no doubt that calcium when administered by the mouth is largely excreted and probably many of the failures in calcium cases are due to the fact that the calcium has never been absorbed.

In cases that need calcium I give ro c.c. of a ro per cent. solution of calcium gluconate intravenously-and to ensure a temporary rise of blood-serum administer 20-40 units of parathormone simultaneously subcutaneously.

Following the injection, when given intravenously there is a feeling of warmth which lasts 3 to 4 seconds, and spreads all over the patient. No other objective effect has ever been elicited as the result of the injection.

Chilblains respond very well to this line of therapy and I have many cases who have been taking calcium orally without success.

In the majority of cases of chilblains no alteration in blood-calcium is discernible. It is my practice in these cases to give calcium injections thrice weekly together with the parathormone.

I have had good results in obstinate cases of acne rosacea. Burgess records cases of urticaria of great severity which cleared up on a calcium parathyroid therapy and I have one dramatic case of an actor whose urticaria (which he knew from previous attacks lasted two to three days) cleared up in two hours following calcium parathormone therapy.

I have several cases of angio-neurotic œdema which are apparently quite well. In one very severe case, the patient, a young woman of 27 , was free of attacks for the first time for two years following a course of calcium-therapy. Every now and again at the present moment she has a relapseand this is very much slighter than it used to be, and this is immediately improved by a calcium injection.

Following the work of Critchley and others, I have tried this treatment in post-encephalitic conditions and paralysis agitans.

In the latter condition in my series of cases there has always been. some improvement, sometimes this has been very marked. The tremor and weakness have become very much less, and salivation, which is so often a distressing feature in these cases, has either diminished or disappeared. Genoscopolamine is very helpful as an adjuvant. The same applies to post-encephalitic conditions. There has always been a slight improvement and in two cases a very definite one. Another group of cases is that of the young girl who suffers from acrocyanosis and œdema of the ankles. These are very troublesome cases, but I have had some very good results with calcium administered as described. Hay fever is yet another of the allergic conditions which have responded well. A doctor friend of mine tells me that this year, when he has had calcium injections, is the first year that he can remember that he has been free of hay fever. He had previously had all the usual therapy including protein sensitization tests and pollen vaccine.

The condition of mucous colitis which is often associated with allergic conditions has also been of benefit. The rationale for this line of treatment may rest on Popescu's work that calcium in small doses stimulates the sympathetic system. In discussion of this question of therapy, the other methods of mobilizing calcium must not be forgotten. They are always valuable and sometimes essential. I refer to ultra-violet light, heliotherapy, and cod-liver oil. Irradiated ergosterol or radiostol also seem to have a very definite value in such cases.

It is realized that a large part of this work is empirical, and the comments of Percival, who states that derangements of calcium metabolism are confined to a very small number of pathological conditions, have been borne in mind; but it is my belief, and this is a belief founded entirely on clinical results, 
that failure in calcium cases is often due to the fact that the calcium has not been absorbed when given by the usual route; and it has been found that the frequent administration of a substance that is apparently quite harmless in the tissues, aided by another which we know definitely produces a rise of blood-calcium, does effect remarkable cures in one of the most difficult and obstinate groups of cases which the clinician is asked to treat. Most of the cases in my series had had long therapy, some had been given up, and this line of treatment was embarked on as a last hope. Of course there have been failures-but then these cases have responded to no other form of therapy. These results are empirical, but they are encouraging and clearly far more work must yet be done before the problem of calcium therapy is solved.

\section{REFERENCES.}

Denis and Minot. Journ. Biol. Chem., 1920, xli, 357. Vines. "Parathyroid in Health and Disease."

ldem. Journ. Physiol., 1921, lv, 86.

MARTLAND and KOBISON. Journ. Biochem., 1927, xxi, 665.

Robison and SoAmas. Biochem. Journ., xviii, 740.

Drummond. Physiological Lectures.

Stewart and Percival. Biochem. Journ., xxi, 301.

Hunter and Aub. Quart. Journ. Med., 1926, xx, 123.

Kramer and Tisdall. Journ. Biol. Chem., I921, xlviii, 475.

Matz. Amer. Kev. Tuber., 1925, xi, 250.

Cantarow and others. Arch. Intern. Med., I926, xxxviii, 502.

Fraser. Brit. Med. Journ., 1927, ii, 777.

Blum. Ibid., 1927, ii, 784 .

Idem. Presse Médicale, March 15, 1922, xxi.

MARRIOTT and Howland. Arch. Intern. Med., 1916, $x$ viii, 708 .

Salvesen and Linder. Journ. Biol. Chem., I923, Iviii, 617.

De Wesselow. Quart. Journ. Med., 1923, xvi, $34 \mathrm{I}$.

LiNDER. Brit. Med. Tourn., 1927, ii, 784.

Popescu. Compt. rend. Soc. de Biol., 1925, xciii, 72.

\section{SURGICAL RESURRECTIONS-VI.}

THE case here related may be taken aso confirmatory evidence of the benefit of the line of treatment adopted in Case 5. Any' case with fæculent vomiting which recovers without operative interference must be् regarded as in the nature of a resurrection. $\frac{O}{0}$

A man, aged 49 , was taken with dull pair. across the umbilical zone of the abdoment: Two hours later he vomited. Next day the pain was felt all over the abdomen but gradually became more severe on the right side. When I saw him on the third day helooked ill, had a rapid pulse (120) and $\mathfrak{x}$ tender distended lower abdomen. It was clear that he had peritonitis and the mosfo probable cause: was appendicitis. I had him moved to the hospital but did nop operate till next day. A mid-line suprapubic incision showed general peritonitis; the pelvis was drained through this incision bu a second cut was made in the right iliaç region for the removal of the appendix which proved to be gangrenous. A tuber was also put into the second incision. The usual after-treatment was carried out-the? patient was put in the sitting-upright positiong and continuous injection of saline given perrectum. Following the operation the temperature fell to $964^{\circ} \mathrm{F}$. and distensiono was very troublesome. Repeated small doses of pituitrin were given and a turpen tine enema administered; 30 c.c. of anti-gaş gangrene serum was given subcutaneously N The next day the distension was worse andu there was black vomit so the stomach waso washed out and more serum given. Theo following day the distension was worse, the vomiting continued, and the vomited material was yellow and fæculent. Theo patient was semi-comatose, and in a des $\stackrel{\vec{\phi}}{\overrightarrow{8}}$ perate condition. The stomach was again $\overrightarrow{\mathbb{Q}}$ washed out and some castor oil left in the viscus. Then an intravenous injection of two pints of normal saline was given and 